
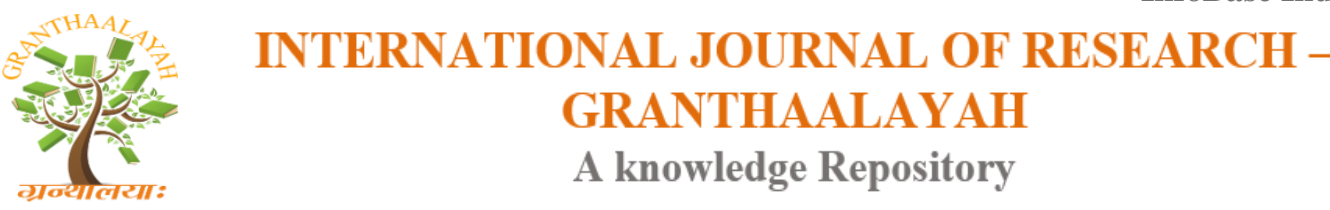

Social

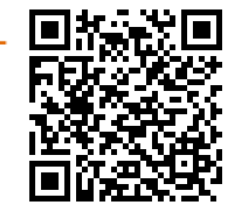

\title{
A TOOL CONSTRUCTION AND STANDARDIZATION OF NUTRITION KNOWLEDGE OF HIGH SCHOOL STUDENTS
}

\author{
T.Indumathi ${ }^{1}$, Dr. N. Ramakrishnan ${ }^{2}$ \\ ${ }^{1}$ Ph.D Scholar, Department of Educational Technology, \\ Tamil Nadu Teachers Education University, Karapakkam, Chennai - 600 097, India \\ ${ }^{2}$ Professor \& Head, Department of Educational Technology, \\ Tamil Nadu Teachers Education University, Karapakkam, Chennai - 600 097, India
}

DOI: https://doi.org/10.29121/granthaalayah.v5.i5(SE).2017.1969

\begin{abstract}
In the present study, Nutrition knowledge scale has been constructed and standardized of the High School Students. This scale consists of 54 statements. The simple random sample technique was used for this study. The sample consists of 50 High School Students are randomly selected from the Kancheepuram Districts. The ' $t$ ' value was sued to standardize the tool and finally 29 statements were retained for the final study.
\end{abstract}

Keywords: Nutrition Knowledge, High School Students.

Cite This Article: T.Indumathi, and Dr. N. Ramakrishnan. (2017). "A TOOL CONSTRUCTION AND STANDARDIZATION OF NUTRITION KNOWLEDGE OF HIGH SCHOOL STUDENTS." International Journal of Research - Granthaalayah, 5(5)SE, 69-74. https://doi.org/10.29121/granthaalayah.v5.i5(SE).2017.1969.

\section{Introduction}

The World Health Organization has stated that nutrition is an input to and foundation for health and development. Proper nutrition makes people stronger and more productive. Healthy eating habits lead to a stronger immune system, less illness, and better health. Proper and healthy nutrition is a fundamental key to a better quality of life (WHO, 2007).

\section{Definition of Nutrition Knowledge}

Nutrition knowledge, broadly defined, refers to knowledge of concepts and processes related to nutrition and health including knowledge of diet and disease, foods representing major sources of nutrients, and dietary guidelines and recommendations. (Axelson \& Brinbery, 1992; Mckinnon, Giskes, \& Turrell, 2014; Moorman, 1996; Parmenter \& Wardle, 1999). 
The nutrition knowledge acquired throughout school life is a factor of interaction between the school curriculum, school environment, the family and community (FAO 2005b).

\section{Objectives of the Study}

The objective of the present investigation to develop a tool to measure the nutrition knowledge of high school students. As there is no suitable tool available for the purpose the investigator has constructed and validated one in order to realize her objectives. The Nutrition Knowledge Inventory (NKI) is a two point scale. i.e. 'Yes' and 'No' type.

\section{Pilot Study}

This inventory of 54 statements intended for pilot study was administrated to the sample, 50 high school students studying in the Kancheepuram district. Then their responses have been scored carefully and the marks secured by all the students have been arranged in the descending order from the highest score to lowest score. Then, they were subjected to item analysis.

\section{Item Analysis}

The next step in the standardization of nutrition knowledge inventory after pilot study is to find out the ' $t$ ' value of each statement which forms the basis for item selection in order to build up the final inventory.

The two point scale calls for 'Yes' or 'No' response to each statement. For positive statements one is given to 'Yes' response and zero is given to 'No' response. The scoring scheme is reversed for the negative statements.

Table 1: Scoring key of the inventory according to the nature of items

\begin{tabular}{|l|l|l|}
\hline Nature of the Items & Yes & No \\
\hline Positive: & & \\
$\mathbf{1}, \mathbf{2}, \mathbf{3}, \mathbf{4}, \mathbf{8}, 10,12,13,14,15,16,17,18,20,24,25,26,27,29,30,31,33,34,35$, & 1 & \\
$36,37,39,41,42,43,44,45,47,48,49,50,51,52,53,54$. & & \\
\hline $\begin{array}{l}\text { Negative: } \\
5,6,7,9,11,19,21,22,23,28,32,38,40,46 .\end{array}$ & & \\
\hline
\end{tabular}

Table 2: Nutrition Knowledge Inventory Dimension wise according to the nature of items

\begin{tabular}{|c|c|c|c|}
\hline Dimension & \multicolumn{2}{|c|}{ Nature of the Items } & Total \\
\hline \multirow{2}{*}{$\begin{array}{llll}\text { Factors } & \text { Regarding } & \text { Source } & \text { of } \\
\text { Nutrition } & & & \end{array}$} & Positive & $1,2,3,4,8,10,12,13,14,15,16,17$ & \multirow[b]{2}{*}{17} \\
\hline & Negative & $5,6,7,9,11$ & \\
\hline \multirow{2}{*}{$\begin{array}{l}\text { Factors Regarding Deficiency of } \\
\text { Nutrients }\end{array}$} & Positive & $18,20,24,25,26$ & \multirow[b]{2}{*}{9} \\
\hline & Negative & $19,21,22,23$ & \\
\hline \multirow[t]{2}{*}{ Factors Regarding Food Habits } & Positive & $27,29,30,31,33,34,35,36$ & \multirow[b]{2}{*}{10} \\
\hline & Negative & 28,32 & \\
\hline \multirow{2}{*}{$\begin{array}{l}\text { Factors Regarding Functions of } \\
\text { Nutrients }\end{array}$} & Positive & $37,39,41,42,43,44,45$ & \multirow[b]{2}{*}{9} \\
\hline & Negative & 38,40 & \\
\hline \multirow{2}{*}{$\begin{array}{l}\text { Factors Regarding Nutritional } \\
\text { Techniques }\end{array}$} & Positive & $47,48,49,50,51,52,53,54$ & \multirow[b]{2}{*}{9} \\
\hline & Negative & 46 & \\
\hline & & Total & 54 \\
\hline
\end{tabular}


Table 3: Nutrition Knowledge Inventory Dimension wise according to the Selected items

\begin{tabular}{|c|c|c|c|}
\hline \multirow{3}{*}{$\begin{array}{l}\text { Dimension } \\
\text { Factors Regarding Source of Nutrition }\end{array}$} & \multicolumn{2}{|c|}{ Nature of the Items } & Total \\
\hline & Positive & $1,2,3,10,12,13,14,15,17$ & \multirow[b]{2}{*}{10} \\
\hline & Negative & 6 & \\
\hline \multirow{2}{*}{$\begin{array}{l}\text { Factors Regarding Deficiency of } \\
\text { Nutrients }\end{array}$} & Positive & $18,24,26$ & \multirow[b]{2}{*}{5} \\
\hline & Negative & 22,23 & \\
\hline \multirow{2}{*}{ Factors Regarding Food Habits } & Positive & $28,29,30,33,35$ & \multirow[b]{2}{*}{6} \\
\hline & Negative & 32 & \\
\hline \multirow[t]{2}{*}{ Factors Regarding Functions of Nutrients } & Positive & $39,42,45$ & \multirow[b]{2}{*}{4} \\
\hline & Negative & 38, & \\
\hline \multirow[t]{2}{*}{ Factors Regarding Nutritional Techniques } & Positive & $47,48,49,50$ & \multirow{2}{*}{4} \\
\hline & Negative & & \\
\hline & & Total & 29 \\
\hline
\end{tabular}

\section{Items Selection}

To select the items to from the final draft of the Nutrition Knowledge Inventory, the difficulty index of the each item was analyzed. According to Edwards (1957), "the value of ' $t$ ' is a measure of the extent to which a given item differentiates between the high and low groups. If the ' $t$ ' value is equal to or greater than 1.96, it indicates that the average response of the high and low groups to a statement differs significantly, provided here are 14 or more subjects in the high group and also in the low group".

The ' $t$ ' value for all the 54 items of the NKI were obtained to select the items for the final draft. Out of 54 items, 29 items were found to be selected as having ' $t$ ' value more than 1.96. They are given in table -3 .

Table 4: Items selected for the draft of the NKI based on their ' $t$ ' value between upper and lower

\begin{tabular}{|c|c|c|c|}
\hline Item No. & 't' Value & Remarks & Item No. in the final draft of Nutrition knowledge \\
\hline 1 & 2.482 & Selected & 1 \\
\hline 2 & 6.904 & Selected & 2 \\
\hline 3 & 2.280 & Selected & 3 \\
\hline 4 & 1.385 & Not Selected & - \\
\hline 5 & 1.000 & Not Selected & - \\
\hline 6 & 2.687 & Selected & 4 \\
\hline 7 & 0.694 & Not Selected & - \\
\hline 8 & 0.806 & Not Selected & - \\
\hline 9 & 1.749 & Not Selected & - \\
\hline 10 & 2.687 & Selected & 5 \\
\hline 11 & 1.794 & Not Selected & - \\
\hline 12 & 2.687 & Selected & 6 \\
\hline 13 & 3.606 & Selected & 7 \\
\hline 14 & 2.280 & Selected & 8 \\
\hline 15 & 3.122 & Selected & 9 \\
\hline
\end{tabular}




\begin{tabular}{|c|c|c|c|}
\hline 16 & 1.000 & Not Selected & - \\
\hline 17 & 2.110 & Selected & 10 \\
\hline 18 & 2.280 & Selected & 11 \\
\hline 19 & 0.322 & Not Selected & - \\
\hline 20 & 1.000 & Not Selected & - \\
\hline 21 & 0.366 & Not Selected & - \\
\hline 22 & 4.163 & Selected & 12 \\
\hline 23 & 2.121 & Selected & 13 \\
\hline 24 & 2.280 & Selected & 14 \\
\hline 25 & 0.000 & Not Selected & - \\
\hline 26 & 2.687 & Selected & 15 \\
\hline 27 & 1.472 & Not Selected & - \\
\hline 28 & 2.876 & Selected & 16 \\
\hline 29 & 3.122 & Selected & 17 \\
\hline 30 & 2.482 & \begin{tabular}{|l|} 
Selected \\
\end{tabular} & 18 \\
\hline 31 & 1.000 & Not Selected & - \\
\hline 32 & 2.121 & Selected & 19 \\
\hline 33 & 2.110 & Selected & 20 \\
\hline 34 & 1.000 & Not Selected & - \\
\hline 35 & 3.122 & Selected & 21 \\
\hline 36 & 0.434 & Not Selected & - \\
\hline 37 & 0.000 & \begin{tabular}{|l|} 
Not Selected \\
\end{tabular} & - \\
\hline 38 & 2.463 & Selected & 22 \\
\hline 39 & 2.687 & Selected & 23 \\
\hline 40 & 0.694 & Not Selected & - \\
\hline 41 & 0.806 & Not Selected & - \\
\hline 42 & 3.606 & Selected & 24 \\
\hline 43 & 1.000 & Not Selected & - \\
\hline 44 & 0.563 & Not Selected & - \\
\hline 45 & 2.110 & Selected & 25 \\
\hline 46 & 0.694 & Not Selected & - \\
\hline 47 & 3.122 & Selected & 26 \\
\hline 48 & 2.121 & Selected & 27 \\
\hline 49 & 2.280 & Selected & 28 \\
\hline 50 & 4.163 & Selected & 29 \\
\hline 51 & 0.694 & Not Selected & - \\
\hline 52 & 1.385 & Not Selected & - \\
\hline 53 & 0.366 & Not Selected & - \\
\hline 54 & 0.563 & Not Selected & - \\
\hline
\end{tabular}

Here, the investigator has mentioned 29 selected statements in below table - 5 
Table 5:

\begin{tabular}{|c|c|c|c|}
\hline S.No & STATEMENTS & YES & No. \\
\hline \multicolumn{4}{|c|}{ Factors Regarding Source of Nutrients } \\
\hline 1 & Carbohydrates are major source of energy for muscle work. & & \\
\hline 2 & Sugars, sweets and unenriched refined cereals provide calories only. & & \\
\hline 3 & Sugar occurs naturally in grapes and other fruits. & & \\
\hline 4 & Butter has less fat. & & \\
\hline 5 & Vitamin-D is naturally available from sun light. & & \\
\hline 6 & Oils, Nuts and Whole grams are the richest sources of the Vitamin-E. & & \\
\hline 7 & Dates are rich in iron. & & \\
\hline 8 & Amaranth, Jaggery, Liver, Rice flakes are rich in iron. & & \\
\hline 9 & Green leafy vegetables are low in calories. & & \\
\hline 10 & Vitamin-C is available in orange. & & \\
\hline \multicolumn{4}{|c|}{ Factors Regarding Deficiency of Nutrients } \\
\hline 11 & Night blindness is due to Vitamin-A deficiency. & & \\
\hline 12 & Osteoporosis is not a calcium related health problem. & & \\
\hline 13 & Scurvy is not related to Vitamin-C. & & \\
\hline 14 & $\begin{array}{l}\text { Mouth ulcers and cracked lips are the symptoms of vitamin B2 } \\
\text { deficiency. }\end{array}$ & & \\
\hline 15 & $\begin{array}{l}\text { Low iodine level in our diet leads to learning difficulties during } \\
\text { childhood. }\end{array}$ & & \\
\hline \multicolumn{4}{|c|}{ Factors Regarding Food Habits } \\
\hline 16 & Carbonated drinks are good for human health. & & \\
\hline 17 & $\begin{array}{l}\text { Lack of increased protein intake during illness will result in } \\
\text { delayed wound healing. }\end{array}$ & & \\
\hline 18 & To reduce Cholesterol level, it is more important to eat less saturated fat. & & \\
\hline 19 & Iodised salt is not good for health. & & \\
\hline 20 & We have to take minimum three litres of water per day. & & \\
\hline 21 & It is harm eating junk foods & & \\
\hline \multicolumn{4}{|c|}{ Factors Regarding Functions of Nutrients } \\
\hline 22 & Body growth can take place without protein. & & \\
\hline 23 & High calorie intake leads to obesity. & & \\
\hline 24 & Iron absorption is enhanced by Vitamin-C. & & \\
\hline 25 & $\begin{array}{l}\text { Iodine is necessary for the normal growth and development of } \\
\text { human brain. }\end{array}$ & & \\
\hline \multicolumn{4}{|c|}{ Factors Regarding Nutrition Education } \\
\hline 26 & Pressure cooking saves nutrients. & & \\
\hline
\end{tabular}




\begin{tabular}{|l|l|l|l|}
\hline 27 & $\begin{array}{l}\text { In stewing method, loss of nutrients is avoided as water used for cooking } \\
\text { is not discarded. }\end{array}$ & & \\
\hline 28 & $\begin{array}{l}\text { Steamed foods like idli and idiappam contain less fat and are easily } \\
\text { digested. }\end{array}$ & & \\
\hline 29 & Parboiling of rice reduces the loss of vitamin B. & & \\
\hline
\end{tabular}

\section{Reliability}

In order to establish the reliability of nutrition knowledge inventory, the spilt - Half method was used. The reliability of nutrition knowledge inventory was found to be 0.95 . Hence, nutrition knowledge inventory was considered as reliable.

\section{Validity}

The index of validity which is the square root of the reliability was found to be 0.97 . Hence, nutrition knowledge inventory selected for the study was considered to be highly valid.

\section{Conclusion}

The investigator is hopeful that this inventory would be helpful to measure the level of Nutrition Knowledge in the high school students. Hence, this tool will be very useful for the investigator to measure to what extent the level of Nutrition Knowledge is in the High School Students and it may be utilized and extended in the same for the future researchers.

\section{References}

[1] Garrett, H.E. (1973). "Statistics in Psychology and Education". Bombay: Vakils, Pfeffer and Simons Pvt. Ltd.

[2] Golden, S. A. R. (2011). Strategy For Success Of Human Beings:-Time Management.

[3] Golden, S. A. R. (2016). RURAL STUDENTS' ATTITUDE TOWARDS ENGLISH AS MEDIUM OF INSTRUCTION IN HIGHER EDUCATION - AN ANALYSIS. International Journal of Research, 3(Special Issue - 16), 1-10.

[4] Golden, S. A. R. (2017). Attitude of Students and Teachers towards E- Learning - An Analysis. Recent Research in Social Science \& Humanities, 1, 5-10.

[5] Golden, S. A. R. (2017). Recent Research In Social Science \& Humanities.

[6] Golden, S. A. R. (2011). Problems and Prospectus of Distance Education. Quality Enhancement In Distance Education For Life Long Learning, 1(1), 343-344.

[7] John. W. best, "Research in Education", 4th Edition, Prentice Hall of India (P) Ltd., New Delhi,

[8] Kothari, C. R. (2000). "Research Methodology"; Methods and Practice Techniques, Wishwa Publication, New Delhi.

[9] Mangal, S.K. (2013). "Educational Psychology". Delhi: Cosmo publication.

[10] Miller, L. M. S, \& Cassady, D. L. (2015). "The effect of nutrition knowledge on food label use. A review of the literature". Appetite, 92(2015), 207-216.

[11] Regi, S. B., \& Golden, S. A. R. (2014). A Study On Attitude Of Employee Towards Working Environment With Special Reference To RR Pvt Ltd. Review Of Research, 2(2), 1-5. 